\title{
Diversity of Ferns (Pteridophyta) in Ancient Volcano Mount Nglanggeran Climbing Track and the Booklet Development for Independent Learning Sources
}

\author{
Iqbal Fajrin Averos, Widodo, Cahya Arsyi Widiyatami*, Wuri Esti Tyas Utami \\ Biology Education Department, Faculty of Science and Technology, UIN Sunan Kalijaga \\ Jl. Marsda Adisucipto No. 1 Yogyakarta 55281, Indonesia. Tel. +62-274-540971, Fax. +62-274-519739 \\ "E-mail: arsyicahya @gmail.com
}

\begin{abstract}
This study aims to determine the diversity of ferns species in Ancient Volcano Mount (Gunung Api Purba) Nglanggeran climbing track and develop the Ferns Booklet as a source of students' independent learning as well as knowing the quality of the product. This type of research is development research $(\mathrm{R} \& \mathrm{D})$ using three stages. The first is taking sampling and identification, second is developing product and the last is trials product. The product was evaluated and validated by material experts, media experts, and 5 peer reviewers. A limited test was conducted by a biology teacher and 15 students of MA Wahid Hasyim Sleman (Islamic Senior High School) by questionnaire method. The results showed that ferns diversity has 39 species by 20 genera in 12 families. Qualitative data from the results are converted into quantitative data. Product quality according to the assessors is in the very good category, with an ideal percentage assessment from the experts, peer reviewers, biology teachers and students respectively 87.59\%; 86.48\%; 84.83\%; and $90.88 \%$. Thus, the Fern Booklet is very suitable to be used as a source of independent learning students.
\end{abstract}

Keywords: Booklet, Fern, Independent Learning Resources

\section{INTRODUCTION}

Indonesia is one of tropical countries with high biodiversity. One of biodiversity in Indonesia is ferns that potential to be developed into learning resources. The introduction of ferns in schools are still limited makes students less attention about ferns around them. For this reason, students need additional knowledge related to ferns to be able to recognize ferns around them. The introduction of ferns to students can be done through learning resources from teachers, media and internet or surrounding environment.

Using a local potential as a learning resource will be more effective for students because what is presented is the things that are around them. Management of local potential-based learning is able to improve cognitive, psychomotor and affective abilities of students (Hatimah, 2006). Ancient Volcano Mount Nglanggeran is one of Ancient Volcanoes in Indonesia. Ancient Volcano Nglanggeran is famous as an ecotourism located in Yogyakarta Special Region which is part of Mount Sewu, stretching from Gunungkidul Yogyakarta, Wonogiri in Central Java to Pacitan in East Java. In Widodo (2015) said that the Ancient Volcano Mount Nglanggeran is an area with almost uninhabited and remnant of ancient volcanic magma so that many unique plants that will be easily found in these locations including ferns.

Ancient Volcano Mount Nglanggeran as a strategic place for growing ferns. This as a reference for research ferns in Ancient Volcano Mount Nglanggeran as a source of students' independent learning. According to Nur (2012), diverse learning resources around students' lives have not been optimally utilized in learning.
There still many teachers in Indonesia make textbooks as the only standard in teaching. This makes students less attention to material presented by the teacher.

Based on the above problems, a research is aimed to determine the diversity of ferns species in the Ancient Volcano Nglanggeran climbing track and ferns booklet development as a source of students' independent learning as well as knowing the quality of the product, hoping to help students learn.

\section{MATERIALS AND METHODS}

This research is divided into three main parts:

First is taking photo species of ferns in Ancient Volcano Mount Nglanggeran and identification the ferns species. Data sampling is conducted by observation. This method is exploring the Ancient Volcano Mount Nglanggeran estimated to be found in ferns by taking several species of ferns, it endeavors to obtained vegetative and generative organs that are used for identification.

Second is develop ferns in Volcano Ancient Mount Nglanggeran booklet. The development phase includes, collect image data, determine design, giving material content to the booklet, fixation with the supervisor, print into a booklet, the final phase of development booklet is revision based on input from supervisor, peer reviewers, material experts and media experts.

Third is testing the Fern Booklet as a learning resource. This stage consists of assessment by experts such as media experts, material experts and peer reviewers. And assessment by learning implementers 
such as biology teachers and the $10^{\text {th }}$ grade Senior High School (SMA/MA) students. Assessment and input obtained from assessors are used as a source product improvement so that it is better, better quality and effective as a learning medium.

\section{RESULTS AND DISCUSSION}

\section{Results}

Based on the results of the study obtained 39 species of ferns in Ancient Volcano Nglanggeran climbing track. The results of identification ferns species found in the Nglanggeran Ancient Volcano.

Table 1. The results of fern species.

\begin{tabular}{|c|c|c|c|c|c|}
\hline$\overline{\text { No }}$ & Family & No & Genus & No & Species \\
\hline 1 & Lycopodiaceae & 1 & Lycopodium & 1 & Lycopodium cernuum \\
\hline \multirow[t]{4}{*}{2} & Selaginellaceae & 2 & Sellaginella & 2 & Selaginella plana \\
\hline & & & & 3 & Selaginella invonvels \\
\hline & & & & 4 & Selaginella delicatula \\
\hline & & & & 5 & Selaginella selaginoides \\
\hline 3 & Hymenophyllaceae & 3 & Tricomanes & 6 & Trichomanes maximum \\
\hline 4 & Gleicheniaceae & 4 & Gleichenia & 7 & Gleichenia Linearis \\
\hline 5 & Lygodiaceae & 5 & Lygodium & 8 & Lygodium flexuosum \\
\hline \multirow[t]{2}{*}{6} & Dennstaedtiaceae & 6 & Lindsaea & 9 & Lindsaea ensifolia \\
\hline & & 7 & Histiopteris & 10 & Histiopteris insica \\
\hline \multirow[t]{12}{*}{7} & Pteridaceae & 8 & Adiantum & 11 & Adiantum philippense L. \\
\hline & & & & 12 & Adiantum raddianum \\
\hline & & & & 13 & Adiantum capillus-veneris \\
\hline & & 9 & Pithyrogramma & 14 & Pithyrogramma calomenalos \\
\hline & & 10 & Pteris & 15 & Pteris exelsa \\
\hline & & & & 16 & Pteris biaurita \\
\hline & & & & 17 & Pteris ensiformis \\
\hline & & & & 18 & Pteris vittata \\
\hline & & & & 19 & Pteris macroptera \\
\hline & & & & 20 & Pteris cretica \\
\hline & & 11 & Vittaria & 21 & Vittaria elongate \\
\hline & & & & 22 & Vittaria ensiformis \\
\hline 8 & Aspleniaceae & 12 & Asplenium & 23 & Asplenium trichomones \\
\hline \multirow[t]{4}{*}{9} & Thelypteridaceae & 13 & Cyclosorus & 24 & Cyclosorus terminarus \\
\hline & & & & 25 & Cyclosorus aridus \\
\hline & & & & 26 & Cyclosorus parasiticus \\
\hline & & & & 27 & Cyclosorus dentatus \\
\hline \multirow[t]{2}{*}{10} & Lamariopsidaceae & 14 & Nephrolepis & 28 & Nephrolepis hirsutula \\
\hline & & & & 29 & Nephrolepis exaltata \\
\hline \multirow[t]{3}{*}{11} & Davaliaceae & 15 & Davallia & 30 & Davallia denticulate \\
\hline & & & & 31 & Davallia (Humata) tyermanii \\
\hline & & & & 32 & Davallia botrychhioides Baker \\
\hline \multirow[t]{7}{*}{12} & Polypodiaceae & 16 & Drynaria & 33 & Drynaria rigidula \\
\hline & & 17 & Microsorium & 34 & Microsorium fortunei (Moore) Ching \\
\hline & & 18 & Phymatosorus & 35 & Phymatosorus scolopendria \\
\hline & & 19 & Pyrrosia & 36 & Pyrrosia pilosselloides \\
\hline & & & & 37 & Pyrrosia longifolia \\
\hline & & & & 38 & Pyrrosia lanceolate \\
\hline & & 20 & Sellliguea & 39 & Selliguea heterocarpa \\
\hline
\end{tabular}


Several species pictures of ferns found in Ancient Volcano Mount Nglanggeran.

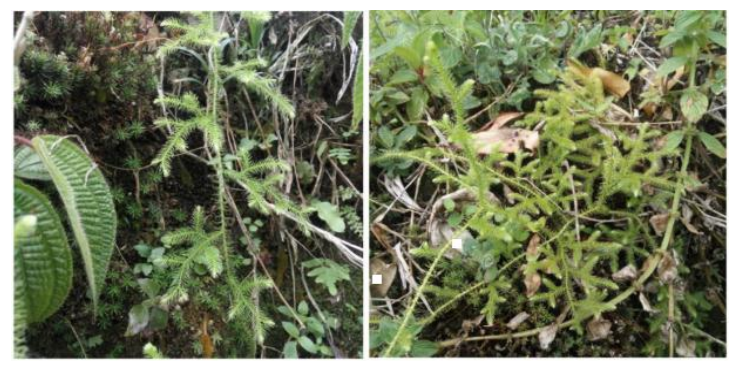

Figure 1. Lycopodium cermum.
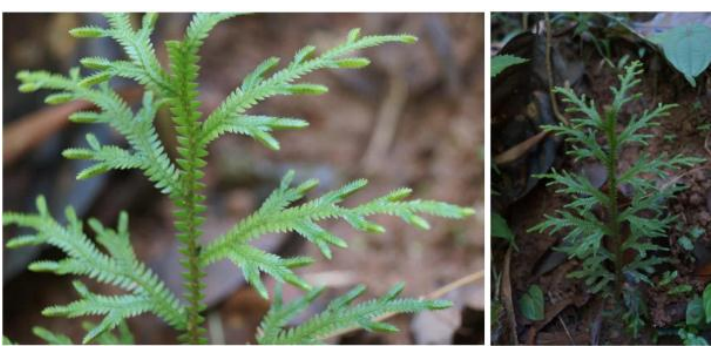

Figure 2: Selaginella selaginoides.
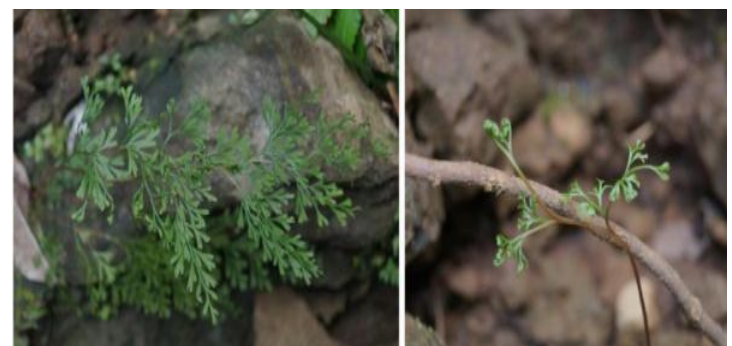

Figure 3. Trichomanes maximum.
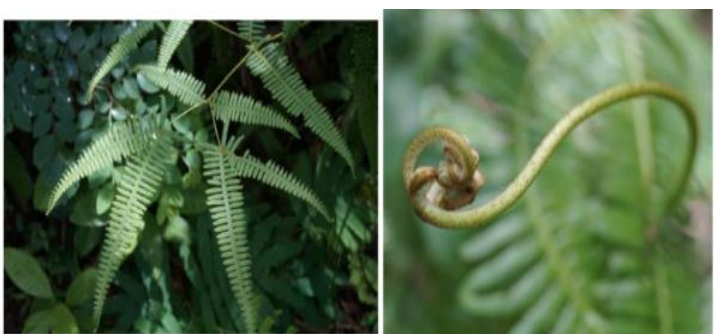

Figure 4. Dicreanopteris linearis.
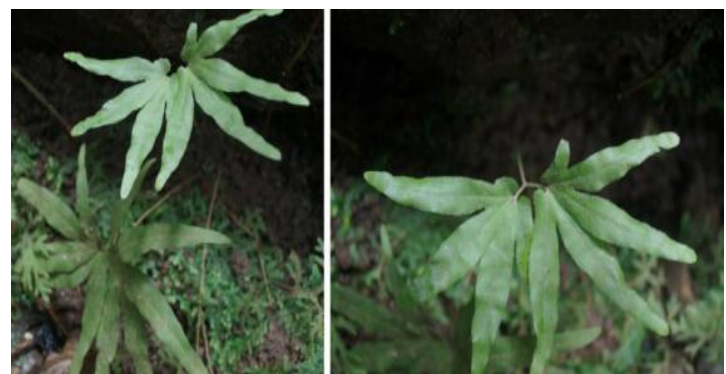

Figure 5. Lygodium flexиosum.
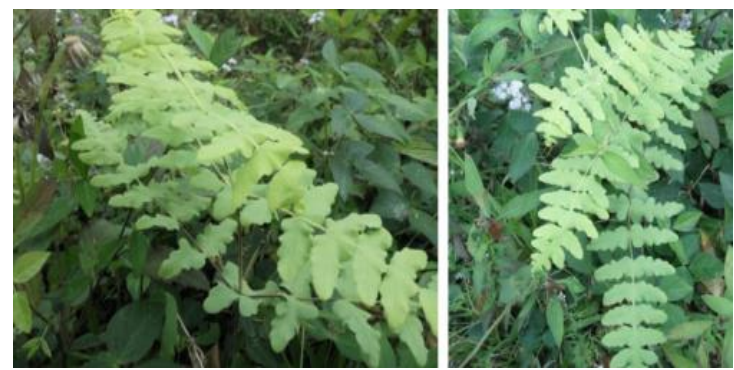

Figure 6. Histipoteris insica.
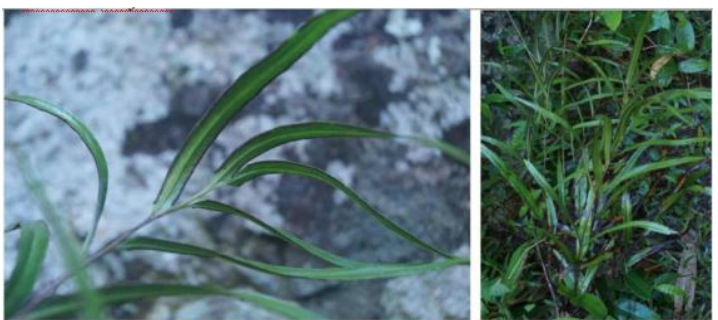

Figure 7. Lindsaea ensifolia.

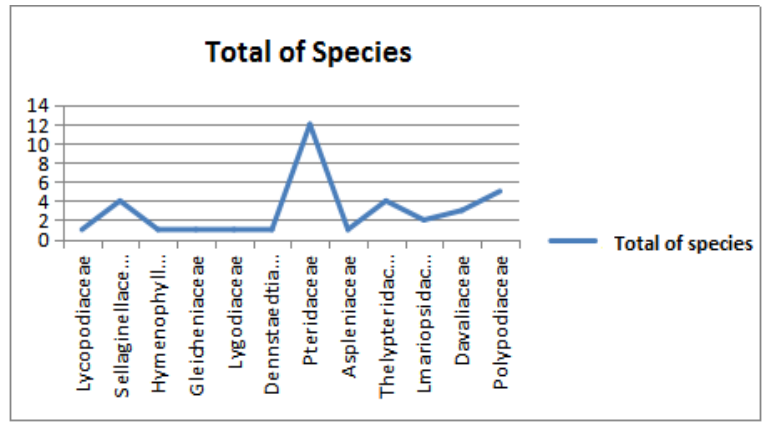

Figure 8. Histogram of the number of species researched at Ancient Volcano Mount Nglanggeran.

Table 2. Assessment of booklets by material experts and media experts aspect.

\begin{tabular}{lllll}
\hline Aspect & $\begin{array}{l}\text { The Highest } \\
\text { Ideal Score }\end{array}$ & $\begin{array}{l}\text { Score } \\
\text { Assessment } \\
\text { Results }\end{array}$ & $\begin{array}{l}\text { Ideals } \\
\text { Percentage } \\
(\%)\end{array}$ & Quality \\
\hline Material & 55 & 51 & 92,73 & Very Good \\
Language & 20 & 18 & 90,00 & Very Good \\
Design & 45 & 36 & 80,00 & Good \\
Operation & 25 & 22 & 88,00 & Very Good \\
Total/Average & 145 & 120 & 87,59 & Very Good \\
\hline
\end{tabular}

Table 3. Booklet assessment results by peer reviewers.

\begin{tabular}{lllll}
\hline Aspect & $\begin{array}{l}\text { The Highest } \\
\text { Ideal Score }\end{array}$ & $\begin{array}{l}\text { Score } \\
\text { Assessment } \\
\text { Results }\end{array}$ & $\begin{array}{l}\text { Ideals } \\
\text { Percentage } \\
(\%)\end{array}$ & Quality \\
\hline Material & 55 & 47,4 & 86,18 & Very Good \\
Language & 20 & 16 & 80,00 & Good \\
Design & 45 & 40,2 & 89,33 & Very Good \\
Operation & 25 & 21,8 & 87,20 & Very Good \\
Total/Average & 145 & 125,4 & 86,48 & Very Good \\
\hline
\end{tabular}


Table 4. Assessment results booklet by biology teachers.

\begin{tabular}{lllll}
\hline Aspect & $\begin{array}{l}\text { The Highest } \\
\text { Ideal Score }\end{array}$ & $\begin{array}{l}\text { Score } \\
\text { Assessment } \\
\text { Results }\end{array}$ & $\begin{array}{l}\text { Ideals } \\
\text { Percentage } \\
(\%)\end{array}$ & Quality \\
\hline Material & 55 & 47 & 85,45 & Very Good \\
Language & 20 & 17 & 85,00 & Very Good \\
Design & 45 & 37 & 82,22 & Very Good \\
Operation & 25 & 22 & 88,00 & Very Good \\
Total/Average & 145 & 114 & 84,83 & Very Good \\
\hline
\end{tabular}

Table 5. Assessment of product quality by grade IX students.

\begin{tabular}{lllll}
\hline Aspect & $\begin{array}{l}\text { The Highest } \\
\text { Ideal Score }\end{array}$ & $\begin{array}{l}\text { Score } \\
\text { Assessment } \\
\text { Results }\end{array}$ & $\begin{array}{l}\text { Ideals } \\
\text { Percentage } \\
(\%)\end{array}$ & Quality \\
\hline Interest & 5 & 4,40 & 88,00 & Very Good \\
$\begin{array}{l}\text { Mastery of the } \\
\text { material }\end{array}$ & 9 & 8,73 & 97,04 & Very Good \\
$\begin{array}{l}\text { Display } \\
\text { Total/ Average }\end{array}$ & 5 & 4,13 & 82,67 & Very Good \\
$\begin{array}{l}\text { Interest } \\
\text { Thery }\end{array}$ & 5 & 17,27 & 90,88 & Very Good \\
\end{tabular}

\section{Discussion}

Based on the results of study, 39 species of ferns were obtained. The results of research data are in the form of ferns photos used to develop ferns booklets in the "ferns diversity" page. Ferns in Indonesia, including Malenesia ferns, are known to be $30 \%$ or 4,400 ferns species from 12,000 ferns species in the world donated from Malesiana region (Winter and Amoroso, 2003). Indonesia is an area with a high diversity of ferns, but the research is still limited. Ferns in Java have estimated around 313 to 500 species (Wanma, 2016). The diversity of ferns becomes more meaningful if it can be applied in contextual biology learning activities (Sulaeman, 2014).

Based on research, it can be concluded that the ferns species found in Ancient Volcano Mount Nglanggeran mostly from Pteridaceae family. Pteridaceae family are more common because they can grow in warm and cold temperatures. Pteridaceae mostly lives in the canopy or open shade, on the ground, stick to the surface of limestone and other rocks (Holtum, 1966). Such conditions almost found in Ancient Volcano Mount Nglanggeran. Photos of species that have been identified are entered into booklets of ferns. A booklet that presents a variety local potential can make easier for students to improve material learned with real conditions. The ease which these students receive encourages them to make a connection between the knowledge they have and the application in life (Mumpuni, 2013).

Booklets are chosen as learning media because the ease of use and quantity is abundant among the general public. Booklet content is prepared based on primary sources and secondary sources. The primary source is based on the first research, namely shooting of ferns and the identification process. Secondary sources come from several books related to ferns including "Plant Taxonomy (Scizophyta, Thallophyta, Bryophyta, Pteridophyta)" by Gembong Tjitrosoepomoe.

Booklet products that have been developed are designed using Adobe Indesign CS5.5 from the start of cover to content layout and layout of photos research results. Material content related to ferns is described from genus level which is presented with documentation of species level entering their respective genera. The sequencing of genus in booklet is adapted to the systematics of ferns from the most ancient level to what can still be found at this time according to the order of systems in Smit et al. (2006). The use of authentic images or photos will generate attraction and facilitate students in understanding content of the material (Syamsi, 2013).

Material in booklet is divided into two materials which are divided into several submitters. Both materials are ferns that include sub spikes in Indonesia, morphology, classification, Ancient Volcano Mount Nglangggeran, and list of species found. The next material is the division of genus which has 20 submaterial containing genus found during the research.

Booklet products that have been developed are then validated by material experts, media experts, peer reviewers, biology teachers and students to find out the quality of overall booklet products developed. The quality is seen from the ideal percentage. Based on the assessment of material experts and media experts, the product has very good quality with an ideal percentage of $87.59 \%$. Almost every aspect has a very good assessment category with the highest acquisition in the material aspect while the lowest aspect in the design aspect. The material aspects include material coverage, material accuracy, problem solving, and finality.

Assessment by peer reviewers provides an ideal percentage data of $86.48 \%$. This shows that the product quality according to peer reviewers is very good. The quality of each aspect almost shows an assessment that has the same category, with the highest results in the design aspect while the lowest is in the aspect of language.

Assessment conducted by biology teachers categorizes products into very good quality. Each aspect has an assessment criteria in a very good category. The operational aspect has the highest quality while the design aspect gets the lowest quality in the assessment given by the biology teacher.

Overall assessment by experts, peer reviewers, and teachers showed that the quality of the products developed was very good with an ideal percentage of $86.20 \%$. The percentage of each aspect also has a value of more than $80 \%$. This shows that overall quality of products developed is very good and is suitable for use as a learning media for high school/MA students. According to Agustina (2012), a product can be said to be feasible if the percentage value is more than $61 \%$.

The product developed has also received a response from students. Student responses showed that $90.88 \%$ choose to agree to fill out the product questionnaire. 
This provides information that the quality of products developed by students belongs to the very good category. Thus it can be said that based on student assessment, the products developed are very feasible to be used as learning media. Some of the things students considered to be an advantage include $100 \%$ of students judging booklets able to increase learning requests with a generally attractive display design and easy to understand the material presented, $93 \%$ of students considered the material presented in accordance with students' abilities. The language used in the booklet also easy to understand by getting a percentage of $93 \%$ of students. The use of learning resources will be able to help and provide opportunities for students, participate in providing a congruent learning experience so that learning goals can be achieved and can increase students' motivation and learning interest (Agustina, 2015).

Overall assessment of the product produced a very good category from experts, peer reviewers, and biology teachers. The results of the student response assessment produce a strongly agree category, so the ferns booklet product that has been compiled and developed is feasible to be implemented as a source of students' independent learning in studying biology.

\section{CONCLUSIONS}

The conclusions obtained from this study are the diversity of ferns in Ancient Volcano consists of 39 types of ferns by 20 genera in 12 families. Booklet products of ferns as a source of independent learning for students have been successfully developed through 3 stages of research. With the first stage is taking species and identification, the second stage is the preparation of the booklet and the final stage is product testing. The quality of booklet products of ferns was developed very well, with an ideal percentage according to experts, peer reviewers and teachers at $87.59 \%, 86.48 \%$, and $84.83 \%$, respectively, while according to students the product valuation was 90.88 $\%$. Products developed can be used as a source of students' independent learning.

\section{ACKNOWLEDGMENTS}

The author would like to thank to the management of apprenticeship program of faculty of science and technology for guidance during the research, to the management of biology, medicine and natural product chemistry \& kaunia journal for assistance in paper writing.

\section{REFERENCES}

Agustina, Devi Yoan. 2015. Pengembangan Bahan Ajar Interaktif sebagai Pendukung Implementasi Pembelajaran Berbasis Scientific Approach pada Materi Jurnal Penyesuaian Siklus Akutansi Perusahaan Jasa di SMK Negeri 1 Jombang. Jurnal Pendidikan Akuntansi. 3: 1-4.

Hatimah, Ihat. 2006. Pengelolaan Pembelajaran Berbasis Potensi Lokal di PKBM. Mimbar Pendidikan. 1. 39-45.

Holttum RE. 1966. A Revised Flora of Malaya. Vol II. Singapura (SG): Government Printing Off.

Mumpuni, Kistantia Elok. 2013. Potensi Pendidikan Keunggulan Lokal Berbasis Karakter dalam Pembelajaran Biologi di Indonesia. Jurnal Pendidikan Biologi Program Pascasarjana Universitas Malang. Vol 10, No 2.

Nur, F. N. 2012. Pemanfaatan Sumber Belajar Dalam Pembelajaran Sains Kelas V SD Pada Pokok Bahasan Makhluk Hidup dan Proses Kehidupan. Jurnal Pendidikan No. 1 Vol 13 diterbitkan pada April 2012.

Smith, A.R, Pryer KM, Schuettpelz E, Korall P, Schneider H, Wolf P.G, 2006. A Classification For Extant Ferns. Taxon 55:705731.

Sulaeman, A.A., Liasari, Redjeki, S. Dan Sawitri, D. 2014 Kreativitas Guru Biologi Dalam Memetakan Komoditas Hayati Unggulan Lokal Ke Dalam Pembelajaran Biologi SMA. Jurnal EDUSAINS: 6 : 98-109.

Syamsi, K., Sari, E.S dan Pujiono, S. 2013. Pengembangan Buku Ajar Membaca Berdasarkan Pendekatan Proses Bagi Siswa SMP. Jurnal Cakrawala Pendidikan XXXII (1):88.

Wanma. A. Ottow., 2016. Keanekaragaman Jenis Tumbuhan Paku (PTRIDOPHYTA) Di Gunung Arfak Papua Barat. Tesis. Sekolah Pascasarjana. Institut Pertanian Bogor.

Wanma. A. Ottow., 2016. Keanekaragaman Jenis Tumbuhan Paku (PTRIDOPHYTA) Di Gunung Arfak Papua Barat. Tesis. Sekolah Pascasarjana. Institut Pertanian Bogor.

Widodo. 2015. Apocynoideae dan Asclepiadoidae dari pegunungan Baturagung (Gunung Nglanggeran, Gunung Mintoro, Gunung Parang, Gunung Gedang, Gunung Ijo): Inisiasi Pencirian dan Konxervasi. Seminar Nasional Konservasi dan Pemanfaatan sumber Daya Alam 2015.

Winter WP dan Amroso VB. 2003. Prosea (2) "Cryptogams: Ferns and Fern Allies". Leiden (DK). Backhuys Publisher. hlm. 26 
THIIS PAGE INTENTIONALLY LEFT BLANK 